\title{
THE
}

7-27-1998

\section{Flight of the Vampire: Ontogenetic Gait-Transition in Vampyroteuthis Infernalis (Cephalopoda: Vampyromorpha)}

\author{
Brad A. Seibel \\ University of Rhode Island, seibel@uri.edu \\ Erik V. Thuesen
}

James J. Childress

Follow this and additional works at: https://digitalcommons.uri.edu/bio_facpubs

Terms of Use

All rights reserved under copyright.

\section{Citation/Publisher Attribution}

Seibel, B.A.; Thuesen, E.V.; Childress, J.J.; 1998. Flight of the vampire: ontogenetic gait-transition in Vampyroteuthis infernalis (Cephalopoda: Vampyromorpha). The Journal of Experimental Biology. 201, 2413-2424.

Available at: http://jeb.biologists.org/content/201/16/2413

This Article is brought to you for free and open access by the Biological Sciences at DigitalCommons@URI. It has been accepted for inclusion in Biological Sciences Faculty Publications by an authorized administrator of DigitalCommons@URI.For more information, please contact digitalcommons-group@uri.edu. 


\title{
FLIGHT OF THE VAMPIRE: ONTOGENETIC GAIT-TRANSITION IN VAMPYROTEUTHIS INFERNALIS (CEPHALOPODA: VAMPYROMORPHA)
}

\author{
BRAD A. SEIBEL*, ERIK V. THUESEN† AND JAMES J. CHILDRESS \\ Oceanic Biology Group, Marine Science Institute, University of California, Santa Barbara, CA 93106, USA \\ *e-mail: seibel@lifesci.ucsb.edu \\ $†$ Present address: The Evergreen State College, Olympia, WA 98505, USA
}

Accepted 3 June; published on WWW 27 July 1998

\begin{abstract}
Summary
Vampyroteuthis infernalis is a cosmopolitan cephalopod that lives in the oxygen minimum layer between 600 and $800 \mathrm{~m}$ depth. Morphometric and physiological studies have indicated that $V$. infernalis has little capacity for jet propulsion and has the lowest metabolic rate ever measured for a cephalopod. Because fin swimming is inherently more efficient than jet propulsion, some of the reduction in energy usage relative to other cephalopods may result from the use of fins as the primary means of propulsion. $V$. infernalis undergoes a rapid metamorphosis which consists of changes in the position, size and shape of the fins. This suggests that there are changes in the selective factors affecting locomotion through ontogeny. The present study describes these changes in relation to models for underwater 'flight'. Citrate synthase (CS) and octopine dehydrogenase (ODH) activities, indicative of aerobic and anaerobic metabolism, respectively, were measured in fin, mantle and arm tissue across a range of body size of four orders of magnitude. The low enzymatic activities in both

increased use of the fins for lift-based propulsion. Fin swimming appears to be the primary means of propulsion at all adult sizes. The negative allometry of CS activity in mantle and arm muscle is consistent with the scaling of oxygen consumption previously measured for $V$. infernalis and with the scaling of aerobic metabolism observed in most animals. The unusual positive allometry of fin muscle CS activity suggests that the use of fins is either relatively more important or more costly in larger animals. Positive scaling of ODH activity in all tissues suggests that fin propulsion, jet propulsion and medusoid 'bell-swimming' are all important for burst escape responses. Enzyme activities in Cirrothauma murrayi are consistent with finswimming observed from submersibles, while those in Opisthoteuthis californiana suggest a strong reliance on medusoid swimming using the arms. The transition from jet propulsion to paired-fin 'flight' with increasing body size in Vampyroteuthis infernalis appears functionally to be an ontogenetic 'gait-transition'.
\end{abstract} posterior and anterior fin tissue and the relatively high activity in mantle muscle prior to metamorphosis indicate that jet propulsion using mantle contraction is the primary means of propulsion in juvenile $V$. infernalis. The increase in CS activity with size after metamorphosis suggests an

Key words: metabolism, scaling, metamorphosis, locomotion, flight, deep-sea, Cephalopoda, Vampyromorpha, Vampyroteuthis infernalis, Cirrata, Opisthoteuthis californiana, Cirrothauma murrayi, Coleoidea.

\section{Introduction}

Vampyroteuthis infernalis Chun, 1903 is a bathypelagic cephalopod which inhabits the oxygen minimum layer $(600-800 \mathrm{~m})$ throughout the world's temperate and tropical oceans. It shares many characteristics with both squids (Order Teuthoidea) and the octopods (Pickford, 1949), but was placed in its own order (Vampyromorpha; Pickford, 1936) primarily on the basis of the presence of sensory filaments (Young, 1967). It was named for its jet-black skin, the caped appearance of the webbing between the arms, and eyes that appear red under some light conditions. Beebe (1926) describes $V$. infernalis as 'a very small but terrible octopus, black as night, with ivory white jaws and blood red eyes'. In contrast to this horrific description, $V$. infernalis appears to be a rather docile

animal. Anatomical studies led Pickford (1949) to suggest that $V$. infernalis spends the majority of its time 'floating, rather than in active progression'. Young (1964) supported this view, saying that $V$. infernalis 'has no more control over its location in the water than that exercised by the common jellyfish'. Seibel et al. (1997) showed that $V$. infernalis has the lowest metabolic rate of any cephalopod ever measured, comparable with that of many medusae (Thuesen and Childress, 1994).

However, in situ and laboratory observations (Hunt, 1996) of Vampyroteuthis infernalis reveal fairly active fin swimming. Broad fins with a well-developed muscular band in the anterior margin attached to the broad gladius (chitinous support structure) appear to be the main means of propulsion (Clarke, 
1988), and the fin muscles, while relatively weak, are the strongest muscles in the animal (Young, 1964). Fin shape (see Lauder and Jayne, 1996) and motion and the surprisingly high swimming speeds observed (Hunt, 1996) in adult vampire squid are consistent with models for underwater 'flight' reported for a variety of taxa (Satterlie et al. 1985; Bannasch, 1994; Davenport et al. 1984; Vogel, 1994; Feldkamp, 1987). The unique 'metamorphosis' observed for $V$. infernalis, which consists of changes in the position, size and shape of the fins (Pickford, 1949), suggests that fin locomotion is important but that the selective factors influencing locomotion change with ontogeny or size. The nature and cause of ontogenetic- (or at least size-) related changes in metabolism and locomotion of all animals, including cephalopods, have been the subject of intense study and debate (Preuss et al. 1997; West et al. 1997; Seibel et al. 1997; Villanueva et al. 1995; Hoar et al. 1994; Webb, 1994; Childress and Somero, 1990; Somero and Childress, 1980, 1985; for a review, see Schmidt-Nielsen, 1984).

Shallow-living squids have extremely high metabolic rates (O'Dor and Webber, 1986) and are known to achieve remarkable speeds from jet propulsion using mantle contraction (Cole and Gilbert, 1970). Deeper-living cephalopods, however, have lower metabolic rates than their shallow-living counterparts resulting from reduced selection for strong locomotory abilities for predator-prey interactions in the light-limited deep sea (Seibel et al. 1997). Where high speed is not a priority, fin propulsion, being more economical than jet propulsion, may be more prevalent. To test this hypothesis and to assess the role of body size and development on metabolism and locomotion, we measured enzymatic activities in fin, mantle and arm tissue of Vampyroteuthis infernalis through ontogeny and metamorphosis. Baldwin (1982) showed that swimming behavior in cephalopods is correlated with the biochemical properties of their locomotory muscles. Citrate synthase (CS) activity was measured as an indicator of aerobic metabolic potential, while octopine dehydrogenase (ODH) activity was used to indicate the potential for glycolytic energy production. For comparison, enzymatic activities were also measured in individuals of two cirrate octopods, Opisthoteuthis californiana and Cirrothauma murrayi.

\section{Materials and methods \\ Collection of animals}

Cephalopods were captured on 10 cruises aboard the R/V Point Sur, R/V New Horizon and R/V Robert Gordon Sproul between March 1993 and September 1996. Sampling was carried out primarily in an area $160 \mathrm{~km}$ west of Point Conception, California $\left(34^{\circ} 37^{\prime} \mathrm{N}, 122^{\circ} 42^{\prime} \mathrm{W}\right.$ to $34^{\circ} 30^{\prime} \mathrm{N}$, $123^{\circ} 20^{\prime} \mathrm{W}$ ). Animals were collected using the opening/closing Mother Tucker trawl with a $10 \mathrm{~m}^{2}$ mouth (Childress et al. 1978). The net was equipped with a 301 thermally protecting cod-end which reduced mechanical damage and heat shock to animals during recovery (Childress et al. 1978). Ship speed was kept very low $\left(0.5-1 \mathrm{knot} ; 0.9-1.9 \mathrm{~km} \mathrm{~h}^{-1}\right)$ to decrease turbulence and skin abrasion of specimens in the net. Specimens were weighed on a motion-compensated ship-board precision balance system (Childress and Mickel, 1980).

The one specimen of Opisthoteuthis californiana (Berry, 1949) was captured in a benthic otter trawl at $500 \mathrm{~m}$ depth in the Santa Barbara Basin $\left(34^{\circ} 17^{\prime} \mathrm{N}, 120^{\circ} 2^{\prime} \mathrm{W}\right)$. Our single rare specimen of Cirrothauma murrayi (Chun, 1913) was captured in midwater at a depth of $2200 \mathrm{~m}$. Animals were generally transferred to chilled sea water and dissected within $24 \mathrm{~h}$ of reaching the surface. All animals, with the exception of Cirrothauma murrayi, were able to swim actively on board ship. C. murrayi appeared freshly dead and was probably killed by either pressure or temperature shock (the animal was too large to fit in the cod-end) within the few minutes prior to reaching the surface. It is not known to what extent the enzymatic activities may have degraded in this specimen. Voucher specimens are housed in the Department of Invertebrate Zoology at the Santa Barbara Museum of Natural History.

\section{Live animal observations}

Immediately following capture, some specimens were placed in ship-board plankton kreisels connected to a chilled seawater system (Monterey Bay Aquarium) for photography and observation. The small size of the aquaria $(0.5 \mathrm{~m}$ in diameter) limited the motion of the animals and so locomotory observations are reported in the text only to augment reports of in situ observations (Hunt, 1996; deGruy and Brown, 1995). Drawings published here are based on personal in situ observations (by J. J. Childress from the DSRV Alvin), shipboard observations (video and photography; B. A. Seibel; David Wrobel, Monterey Bay Aquarium), in situ video analysis (deGruy and Brown, 1995) and preserved specimens.

\section{Dissections}

Tissue was extracted from the left ventral mantle, left anterior fin $\left(\right.$ fin $\left._{\mathrm{a}}\right)$ and/or left posterior fin ( fin $_{\mathrm{p}}$ ) depending on ontogenetic stage, and left second arm of each cephalopod examined. Depending on size, it was not always possible to sample muscle from precisely the same location. To obtain sufficient muscle tissue for enzyme homogenates from very small animals, a larger proportion of muscle had to be taken. Tests conducted on larger animals indicated that there were no significant differences in enzyme activity along the length of the mantle, arm or fin. All samples were frozen immediately in liquid nitrogen following dissection.

It has been shown that the mantle muscle of some cephalopods is divided into distinct layers analogous to vertebrate white and red muscle (Mommsen et al. 1981; Bone et al. 1981) and that the relative proportions of these layers change through ontogeny (Preuss et al. 1997). No attempt was made to locate or sample muscle layers separately. The musculature of vampyromorph and cirromorph cephalopods is covered by a gelatinous tissue that was removed prior to freezing.

\section{Enzymatic activity measurements}

Sections of approximately $0.5 \mathrm{~g}$ of fin, mantle or arm tissue 
were homogenized in varying dilutions of $0.01 \mathrm{moll}^{-1}$ Tris homogenization buffer, $\mathrm{pH} 7.5$, at $10^{\circ} \mathrm{C}$ in Duall hand-held glass homogenizers kept on ice. The homogenate was centrifuged at $6600 \mathrm{~g}$ for $5 \mathrm{~min}$ at $5{ }^{\circ} \mathrm{C}$. Samples $(25-50 \mu \mathrm{l})$ of the supernatant were placed in $1 \mathrm{ml}$ quartz cuvettes under nonlimiting substrate conditions to be assayed for enzyme activity. Enzymatic activities were measured using a Shimadzu UV160U spectrophotometer equipped with a water-jacketed cuvette holder connected to a recirculating water bath. Measurements were carried out at $20^{\circ} \mathrm{C}$. This temperature is considerably higher than in situ temperatures for $V$. infernalis $\left(4-6{ }^{\circ} \mathrm{C}\right)$, but within the working temperature range for the enzymes of this species (B. A. Seibel, unpublished data). The measurement temperature chosen here facilitates detection of enzymes that are present in low concentrations.

Enzyme activities are expressed as units ( $\mu \mathrm{mol}$ of substrate converted to product per minute) per gram wet mass of animal tissue. Octopine dehydrogenase (ODH; EC.1.5.1.11) and lactate dehydrogenase (LDH; EC.1.1.1.8) were assayed as indicators of anaerobic metabolic potential according to the methods of Baldwin and England (1980). Alanopine dehydrogenase activity was not detected. ODH catalyzes the terminal glycolytic reaction in cephalopods resulting in the reductive condensation of pyruvate and arginine to form octopine. As the rate of this reaction is the sum of ODH and LDH activities, ODH activities were obtained by subtracting the rate due to LDH assayed in the absence of arginine.

Citrate synthase (CS; EC.4.1.3.7) was measured as a correlate of aerobic metabolic rate. It was assayed according to the methods of Thuesen and Childress (1994). CS is an important regulatory enzyme and functions in the first step of the citric acid cycle.

\section{Statistical analyses}

Data analyses were performed using Statview II or SuperANOVA statistics programs (Abacus Concepts, Inc., Berkeley, CA, USA). Simple linear regressions and analysis of covariance (ANCOVA) were used. All regressions were carried out on $\log _{\mathrm{e}}$-transformed data to linearize the data and to maintain consistency with previous studies. Standard errors for regression exponents are at the $95 \%$ level of confidence and $P$-values for regression coefficients are from $F$-tests. ANCOVA was used to test whether the slopes and elevations of the various relationships were significantly different from zero and from each other. Regression slopes were declared significant when their slopes differed from zero at the $95 \%$ confidence level.

For consistency with previous studies, mass-specific enzymatic activities $(y)$ were related to wet body mass $(M)$ using the allometric equation $y=a M^{b}$, where $a$ is a constant and $b$ is the scaling exponent. A positive or negative value of $b$ indicates increasing or decreasing specific activity, respectively, with body mass. Aerobic metabolic variables generally scale with a negative exponent, while anaerobic variables often scale with a positive exponent (Childress and Somero, 1990).

\section{Reynolds numbers}

Reynolds numbers were calculated for $\mathrm{fin}_{\mathrm{p}}$ and $\mathrm{fin}_{\mathrm{a}}$ according to the equation:

$$
R_{\mathrm{c}}=U \times c / v,
$$

where $R_{\mathrm{c}}$ is the Reynolds number based on chord length ( $c$; in meters) of the fin, $U$ is velocity $\left(\mathrm{m} \mathrm{s}^{-1}\right)$ and $v$ is kinematic viscosity $\left(1.39 \times 10^{-6} \mathrm{~m}^{2} \mathrm{~s}^{-1}\right)$ (Vogel, 1994). Chord length (fin width) was calculated using Pickford's (1949) measurements of mean fin index (fin width $\times 100 / \mathrm{ML}$, where ML is mantle length) because chord length was not measured on the specimens used in the present study. The fin index was 26 for posterior fins and 49 for anterior fins. Maximum swimming speed was taken as 2 body lengths $\mathrm{s}^{-1}$ estimated from in situ observations (Hunt, 1996).

\section{Metamorphosis}

Pickford (1949) thoroughly described the ontogenetic changes in fin assemblage, body proportions and general musculature in Vampyroteuthis infernalis. However, a brief synopsis is included here to emphasize aspects important to a discussion of locomotion (Fig. 1).

At all stages, the arms of $V$. infernalis are connected by an extensive web, equally developed between all arms. The mantle is short and broad. A funnel-locking apparatus and medial pallial adductor muscle are lacking, which led Pickford (1949) to suggest that $V$. infernalis has little capacity for generating powerful jet thrust. A subcutaneous layer of gelatinous tissue overlies thicker musculature. The funnel is

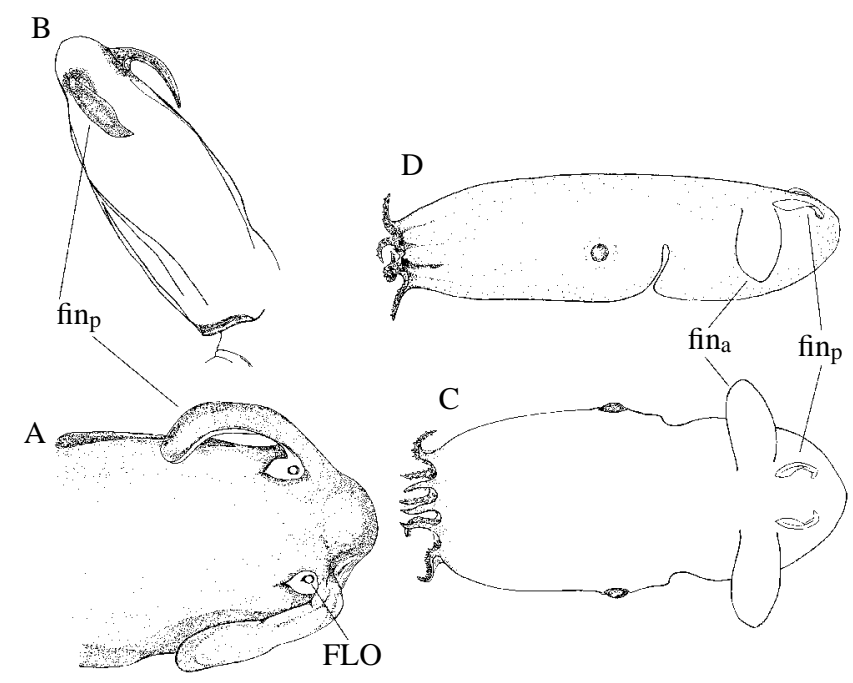

Fig. 1. (A,B) A juvenile Vampyroteuthis infernalis (mantle length, $\mathrm{ML}=10 \mathrm{~mm}$; drawn from a preserved specimen) showing the posterior location and oblique insertion of the posterior fins ( fin $_{\mathrm{p}}$ ). The fin light organ (FLO) is also shown. The anterior fin $\left(\mathrm{fin}_{\mathrm{a}}\right)$ rudiments are not yet visible. (A) Dorsal view. (B) Dorso-lateral (oblique view). (C,D) Four-fin juvenile stage $(\mathrm{ML}=25 \mathrm{~mm}$; drawn from ship-board video footage). (C) Dorsal view. (D) Lateral view showing differing insertions of anterior $\left(\mathrm{fin}_{\mathrm{a}}\right)$ and posterior $\left(\mathrm{fin}_{\mathrm{p}}\right)$ fins. 
embedded in the gelatinous tissue so that directional control of a jet is limited.

At hatching, Vampyroteuthis infernalis resembles other squid hatchlings in that the mantle is large and sac-like. However, at stages larger than $8 \mathrm{~mm}$ mantle length (ML), Vampyroteuthis infernalis takes on the appearance of an adult with the exception of fin complement. At this stage, which we will call juvenile, these squid have a pair of fins $\left(\mathrm{fin}_{\mathrm{p}}\right)$ inserted at the posterior end of the body with the broad side of the fin parallel to the vertical plane when the animal is in its natural horizontal swimming position (Hunt, 1996). An anterior fin rudiment is visible but not yet functional. The $\mathrm{fin}_{\mathrm{p}}$ has an internal cartilage similar to that of cirrate octopods and is considered to be the homologue of the octopod and decapod fins (Young and Vecchione, 1996). The smallest specimen in this study (Fig. 1A,B; $0.5 \mathrm{~g} ; 10 \mathrm{~mm}$ ML) falls within Pickford's (1949) stage 1 category that includes all juveniles with only one pair of fins. Because the fins were too small, no enzyme measurements were made for fin tissue from this specimen.

Just beyond $10 \mathrm{~mm}$ ML (stage 2; Pickford, 1949), the anterior fin $\left(\mathrm{fin}_{\mathrm{a}}\right)$ rudiment begins a stage of rapid growth. The fin $_{\mathrm{a}}$ is inserted more anteriorly, with the broad side perpendicular to the vertical plane, again assuming a horizontal swimming position. The anterior fin has no internal cartilage except where it attaches to the body (Young and Vecchione, 1996). The fin musculature is 'L-shaped' (Young and Vecchione, 1996) and probably has a hydrostat arrangement similar to that of other cephalopod fins (Kier, 1989). The anterior and posterior fins are subequal in length from 15 to $26 \mathrm{~mm}$ ML. At a mean ML of $23 \mathrm{~mm}$ (Fig. 1C,D: $7.6 \mathrm{~g}$; stage 4; Pickford, 1949), the anterior fins overtake the posterior fins in length. The posterior fins are then rapidly resorbed, and the growth rate of the anterior fins decreases to an approximately isometric rate (anterior fin length $=0.51 \mathrm{ML}^{1.01}$ ). At an ML of 26-30 mm, the fin transition is complete. We will refer to all post-metamorphic (fin $\mathrm{p}_{\mathrm{p}}$ resorbed) specimens as adult.

There are other changes that occur through ontogeny that may also have implications for locomotion (Pickford, 1949). There is an increase in the arm length relative to mantle length. While there is no significant breakpoint at metamorphosis, the positive allometry of arm length relative to mantle length means that adult Vampyroteuthis infernalis have much shorter mantle lengths (and smaller mantle cavity volumes) relative to total length than do juvenile individuals. The added arm length may play a role in counterbalance during fin swimming and may also be important for directional control. There are also slight changes in web depth, gladius width and funnel length through ontogeny.

Cephalopod size in the literature is generally presented in terms of dorsal mantle length (ML) measured from the tip of the mantle to the midpoint between the eyes; however, for physiological measurements, body mass $(M)$ is generally more appropriate. For specimens in our study, Vampyroteuthis infernalis $\mathrm{ML}(\mathrm{mm})$ is related to $M(\mathrm{~g})$ by the equation: $\left.\mathrm{ML}=12.5 M^{0.30} ; r^{2}=0.89 ; P=0.0001, N=17\right)$. Please note that ML here is presented in millimeters by convention, but that Reynolds numbers are calculated in meters.

\section{Results \\ Enzyme activities}

The activities of octopine dehydrogenase (ODH), lactate dehydrogenase (LDH) and citrate synthase (CS) in mantle, fin (anterior and posterior for $V$. infernalis) and arm muscle tissue for Vampyroteuthis infernalis, Opisthoteuthis californiana and Cirrothauma murrayi are presented in Table 1. Enzymatic activity and rate of oxygen consumption $\left(\dot{M}_{\mathrm{O}_{2}}\right)$ were not measured for the same specimens except in a few cases. Therefore, no direct correlation could be drawn. However, $V$. infernalis mantle muscle citrate synthase (CS) activity and mass-specific $\dot{M}_{\mathrm{O}_{2}}$ scale with similar slopes (Fig. 2). Solving one equation for the other yields the predictive relationship: $\dot{M}_{\mathrm{O}_{2}}=0.37$ (CS activity) ${ }^{1.09}$. Mantle tissue CS activity (Fig. 2) was significantly higher than that found in arm tissue (Fig. 3; ANCOVA; $P=0.001)$. Anterior fin tissue CS activity in postmetamorphic animals (Fig. 4) scaled with a significantly different slope from either mantle or arm tissue CS. Postmetamorphic fin $_{\mathrm{a}} \mathrm{ODH}$ activity (Fig. 5) was not significantly higher than mantle ODH activity (Fig. 5; ANCOVA; $P=0.06$ ) but was significantly higher than arm $\mathrm{ODH}$ activity (Fig. 3; ANCOVA; $P=0.04$ ). Mantle ODH activity was not significantly higher than arm tissue ODH activity (ANCOVA; $P=0.15$ ) (Fig. 5). LDH activity scaled similarly to $\mathrm{ODH}$ activity (Table 2) but was generally less than $10 \%$ of $\mathrm{ODH}$ activity in all tissues at all sizes (Table 1) and so will not be considered further.

The highest activities of both CS and ODH for Opisthoteuthis californiana (22.6g) were found in arm tissue (Table 1). CS activity for this specimen was higher in fin than in mantle tissue, but the relationship was reversed for $\mathrm{ODH}$ activity. Cirrothauma murrayi (approximately $3000 \mathrm{~g}$ ) had

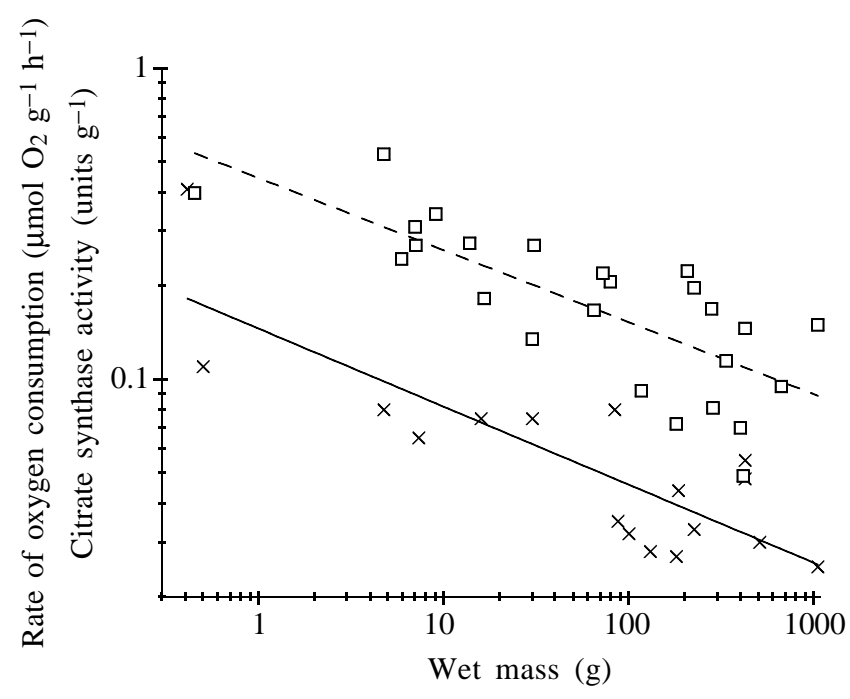

Fig. 2. Rates of oxygen consumption taken from Seibel et al. (1997) $\left(\mu \mathrm{molO} \mathrm{O}_{2} \mathrm{~g}^{-1} \mathrm{~h}^{-1} ; \times\right)$ and citrate synthase (CS) activity (units $\left.\mathrm{g}^{-1}\right)$ in mantle tissue $(\square)$ as a function of animal wet mass $M(\mathrm{~g})$. The regression equation for rates of oxygen consumption is $y=0.15 M^{-0.25 \pm 0.09}\left(r^{2}=0.70, P=0.0001, N=17\right)$. Regression equations for enzymatic activities are given in Table 2 . 
Table 1. Range of enzymatic activities in mantle (man), anterior fin ( fin $\left._{a}\right)$, posterior fin ( $\left(\mathrm{fin}_{p}\right)$ and arm tissue of Vampyroteuthis infernalis (Vampyromorpha), Opisthoteuthis californiana and Cirrothauma murrayi (Octopoda: Cirrata)

\begin{tabular}{|c|c|c|c|c|c|}
\hline Species & Tissue & Wet mass (g) & $\begin{array}{l}\text { Citrate synthase } \\
\text { activity } \\
\text { (units } \mathrm{g}^{-1} \text { wet mass) }\end{array}$ & $\begin{array}{l}\text { Octopine dehydrogenase } \\
\text { activity } \\
\text { (units } \mathrm{g}^{-1} \text { wet mass) }\end{array}$ & $\begin{array}{l}\text { Lactate dehydrogenase } \\
\text { activity } \\
\text { (units } \mathrm{g}^{-1} \text { wet mass) }\end{array}$ \\
\hline \multirow[t]{4}{*}{ Vampyroteuthis infernalis } & $\operatorname{man}$ & $0.45-1050$ & $0.05-0.53(25)$ & $0.06-11.22(27)$ & $0.01-0.35(27)$ \\
\hline & $\operatorname{fin}_{\mathrm{a}}$ & $4.74-1050$ & $0.11-1.35(23)$ & $0.05-20.19(26)$ & $0.02-0.67(26)$ \\
\hline & $\operatorname{fin}_{\mathrm{p}}$ & $4.74-9.05$ & $0.10-0.16(4)$ & $0.02-00.24(4)$ & $0.01-0.04(4)$ \\
\hline & arm & $0.45-666$ & $0.03-0.14(14)$ & $0.08-05.06(14)$ & $0.00-0.10(14)$ \\
\hline \multirow[t]{3}{*}{ Opisthoteuthis californiana } & $\operatorname{man}$ & 22.6 & $0.08(1)$ & $1.34(1)$ & $0.21(1)$ \\
\hline & fin & & $0.12(1)$ & $0.93(1)$ & $0.21(1)$ \\
\hline & arm & & $0.24(1)$ & $5.25(1)$ & $0.57(1)$ \\
\hline \multirow[t]{3}{*}{ Cirrothauma murrayi } & $\operatorname{man}$ & $\approx 3000$ & $0.53(1)$ & $0.05(1)$ & $0.03(1)$ \\
\hline & fin & & $0.11(1)$ & $0.97(1)$ & $0.02(1)$ \\
\hline & arm & & $0.12(1)$ & $0.30(1)$ & $0.02(1)$ \\
\hline
\end{tabular}

Values are ranges with $N$ given in parentheses.

man, mantle; fin $n_{a}$, anterior fin; fin $n_{p}$, posterior fin; arm, arm tissue.

highest CS activity in mantle muscle, but ODH activity was highest in fin tissue (Table 1).

\section{Scaling}

Vampyroteuthis infernalis enzymatic activities in relation to body mass are presented in Table 2 . CS and ODH activity scaled significantly with body mass for all tissues measured with the exception of the posterior fin (Figs 4, 5). LDH activity scaled significantly with body mass for mantle and

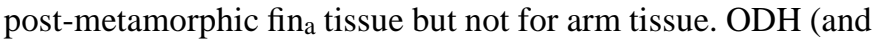
LDH where significant) activity scaled positively $(b>0$; Figs 3, 5). There was no significant difference in the slopes between fin $_{\mathrm{a}}$, mantle and arm tissue ODH activity versus body mass. CS activity scaled negatively for mantle and arm tissue $\left(b<0\right.$; Figs 2, 3) but positively for fin $_{\mathrm{a}}$ tissue (Fig. 4). The slope for post-metamorphic fin ${ }_{\mathrm{a}} \mathrm{CS}$ activity versus body mass was significantly different from that for mantle or arm tissue CS activity (ANCOVA; $P=0.0001$ ). In smaller animals,

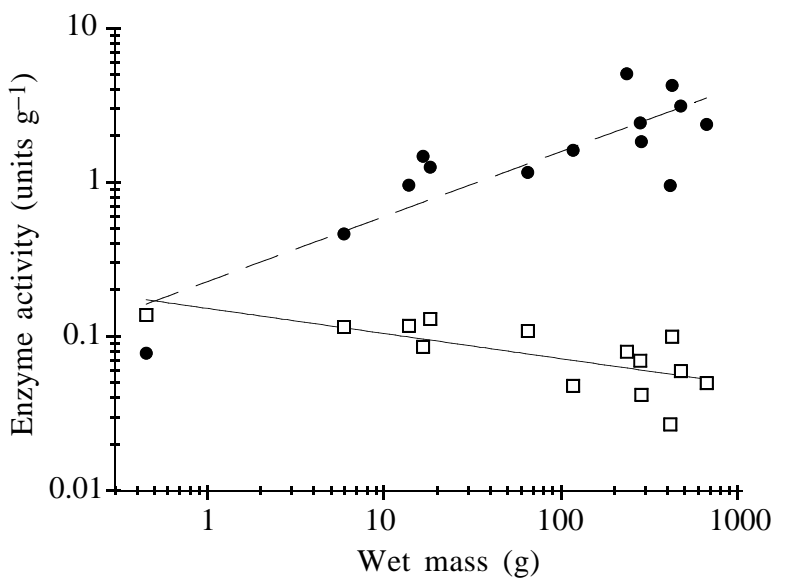

Fig. 3. Citrate synthase (CS, $\square$ ) and octopine dehydrogenase (ODH, -) activity in arm muscle tissue as a function of animal wet mass. Regression equations are presented in Table 2. mantle CS activity approaches or surpasses the activity of CS in fin tissue (Fig. 4). At larger sizes, fin ${ }_{a}$ tissue CS activity diverges from both arm and mantle tissue CS activity. There appears to be a break point in the scaling curve for $\mathrm{fin}_{\mathrm{a}} \mathrm{ODH}$ activity (Fig. 5) and, to a lesser extent, for fin ${ }_{a}$ CS activity (Fig. 4). The four smallest individuals (pre-metamorphic) have $\mathrm{fin}_{\mathrm{a}} \mathrm{ODH}$ and CS activities which scale with a much

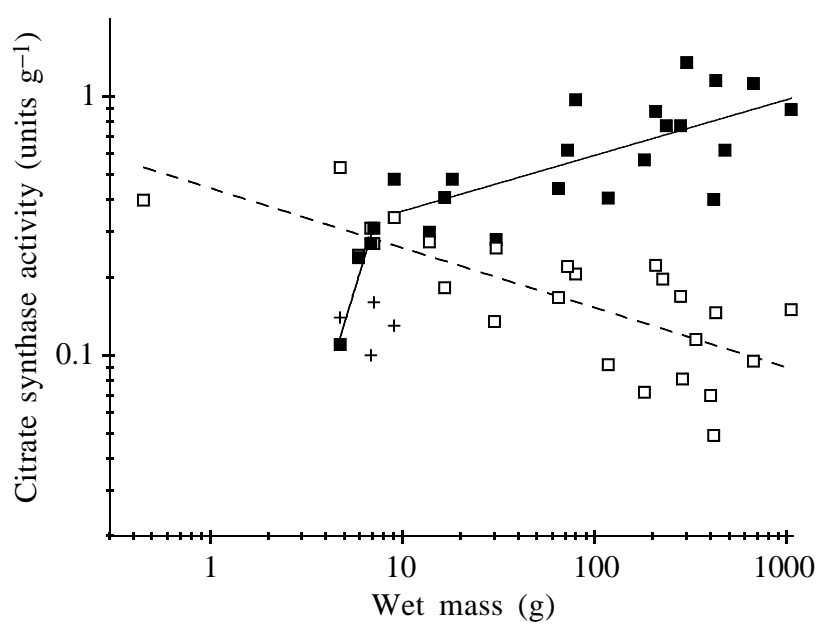

Fig. 4. Citrate synthase (CS) activity in anterior fin $\left(\mathrm{fin}_{\mathrm{a}} ; \mathbf{\square}\right)$ and posterior fin $\left(\mathrm{fin}_{\mathrm{p}} ;+\right)$ tissue as a function of animal wet mass. For comparison, mantle muscle CS ( $\square$ ) activity from Fig. 2 is shown as well. Two separate regressions are drawn for anterior fin data (equations are presented in Table 2). Values for four animals smaller than $23 \mathrm{~mm}$ mantle length are plotted separately as this is the point at which the posterior fin is reabsorbed and the anterior fin reaches adult proportions. Both regressions are significantly different from zero (Table 2) but not from each other (ANCOVA; $P>0.1$ ). The two regressions meet at a wet mass of $7.19 \mathrm{~g}$. The slope of the postmetamorphosis $\mathrm{fin}_{\mathrm{a}}$ regression is significantly different from that of mantle tissue CS (ANCOVA; $P=0.0001$ ). No significant relationship between fin $_{\mathrm{p}} \mathrm{CS}$ activity and body mass exists within the small size range sampled. 


\section{B. A. Seibel, E. V. Thuesen and J. J. Childress}

Table 2. Enzymatic activity (y; units $g^{-1}$ wet mass) in mantle, pre-metamorphic $(<8 \mathrm{~g})$ and post-metamorphic $(>8 \mathrm{~g})$ anterior fin $\left(\right.$ fin $\left._{a}\right)$ and arm tissue of Vampyroteuthis infernalis as a function of wet body mass $(\mathrm{M}), \mathrm{y}=\mathrm{aM}^{\mathrm{b}}$

\begin{tabular}{|c|c|c|c|c|c|c|c|c|c|c|c|c|c|}
\hline \multirow[b]{2}{*}{ Tissue } & \multirow{2}{*}{$\begin{array}{l}\text { Wet mass } \\
\text { range }(\mathrm{g})\end{array}$} & \multicolumn{4}{|c|}{ Citrate synthase } & \multicolumn{4}{|c|}{ Octopine dehydrogenase } & \multicolumn{4}{|c|}{ Lactate dehydrogenase } \\
\hline & & $a$ & $b$ & $N$ & $r^{2}$ & $a$ & $b$ & $N$ & $r^{2}$ & $a$ & $b$ & $N$ & $r^{2}$ \\
\hline Mantle & $0.45-1050$ & 0.44 & $-0.23 \pm 0.04$ & 25 & 0.58 & 0.39 & $0.41 \pm 0.08$ & 27 & 0.54 & 0.03 & $0.25 \pm 0.05$ & 27 & 0.16 \\
\hline $\operatorname{fin}_{\mathrm{a}}$ & $4.74-7.04$ & 0.00 & $2.38 \pm 0.43$ & 4 & 0.94 & 0 & $5.98 \pm 0.02$ & 4 & 0.99 & & NS & & \\
\hline $\operatorname{fin}_{\mathrm{a}}$ & $9.02-1050$ & 0.22 & $0.22 \pm 0.06$ & 19 & 0.44 & 0.61 & $0.49 \pm 0.07$ & 22 & 0.86 & 0.03 & $0.41 \pm 0.12$ & 22 & 0.35 \\
\hline Arm & $0.45-1050$ & 0.15 & $-0.16 \pm 0.05$ & 14 & 0.50 & 0.23 & $0.42 \pm 0.07$ & 14 & 0.74 & & NS & & \\
\hline
\end{tabular}

Values are means \pm S.E.M.

$P=0.03$ for pre-metamorphic fin a and $P=0.04$ for mantle tissue lactate dehydrogenase.For all others, $P<0.005$. NS, not significant.

greater slope than do these enzyme activities in larger individuals (Table 2). To determine the exact size at which the break point occurs, we set the pre- and post-breakpoint curves equal to each other and solved for mass. The break point occurs at a mass of $8.0 \mathrm{~g}$ for $\mathrm{ODH}$ activity and $7.19 \mathrm{~g}$ for CS activity (approximately $23 \mathrm{~mm} \mathrm{ML}$ ). These values fall within the size range at which the anterior fin overtakes the posterior fin in size (Pickford, 1949). Posterior fin activities for CS and ODH are shown in Figs 4 and 5 respectively. All fin $_{\mathrm{p}}$ activities are comparatively low, and no significant relationships with body mass could be determined.

Calculated Reynolds numbers $\left(R_{\mathrm{c}}\right)$ for posterior and anterior fins are plotted against mantle length in Fig. $6 . R_{\mathrm{c}}$ ranged from 28 to 66 for posterior fins and from 160 to 14000 for anterior fins.

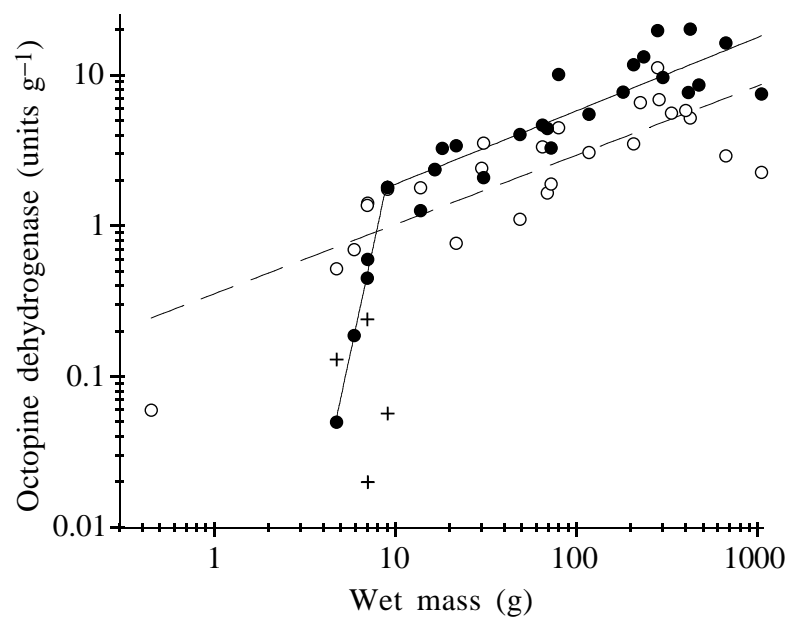

Fig. 5. Octopine dehydrogenase $(\mathrm{ODH})$ activity as a function of animal wet mass for anterior fin $\left(\mathrm{fin}_{\mathrm{a}} ; \mathbf{O}\right)$, posterior fin $\left(\mathrm{fin}_{\mathrm{p}} ;+\right)$ and mantle tissue $(\bigcirc)$ of Vampyroteuthis infernalis. A separate regression is computed for fin $\mathrm{a}_{\mathrm{a}}$ tissue from four animals smaller than $23 \mathrm{~mm}$ mantle length (average size of metamorphosis). This regression line is extrapolated to meet the regression for postmetamorphic fin $_{\mathrm{a}}$ tissue ODH activity. The two regressions meet at a wet mass of $8.0 \mathrm{~g}$. No significant relationship exists between $\mathrm{fin}_{\mathrm{p}}$ $\mathrm{ODH}$ activity and body mass within the small body size range sampled. Regression equations are presented in Table 2.

\section{Discussion}

Enzymatic activities: comparisons with other cephalopods

In agreement with the finding that metabolic rates are generally lower in deep-living, visually orienting pelagic animals (Seibel et al. 1997; Childress, 1995), the activities of all three enzymes measured in the tissues of Vampyroteuthis infernalis are low compared with those of the few similarly sized shallow-living cephalopods that have been investigated (Ballantyne et al. 1981; Baldwin, 1982). Surprisingly, however, $\mathrm{fin}_{\mathrm{a}} \mathrm{ODH}$ activity in larger $V$. infernalis (20.19 units $\mathrm{g}^{-1}$ at $20^{\circ} \mathrm{C}$; Table 1, Fig. 5) approaches that found in smaller specimens $(15-45 \mathrm{~g})$ of the market squid Loligo opalescens $\left(50 \pm 26\right.$ units $\mathrm{g}^{-1}$ at $25^{\circ} \mathrm{C}$; Ballantyne et al. 1981). However, if enzymatic activities of $L$. opalescens scale like those of $V$. infernalis, then $V$. infernalis enzymatic

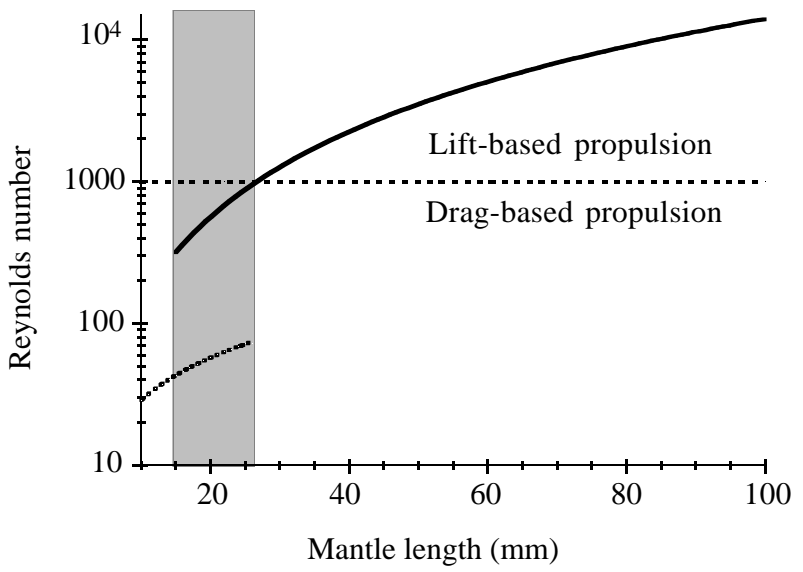

Fig. 6. Reynolds numbers $\left(R_{\mathrm{C}}\right)$ for anterior (solid curve; $R_{\mathrm{C}}=1.4 \mathrm{ML}^{2}$, where ML is mantle length) and posterior (broken curve; $R_{\mathrm{C}}=2.9 \mathrm{ML}^{0.99}$ ) fins of Vampyroteuthis infernalis calculated from fin chord length data (Pickford, 1949) and an estimated swimming speed of 2 body length $\mathrm{s}^{-1}$ (Hunt, 1996). The shaded region represents the stage between 15 and $26 \mathrm{~mm}$ ML when the anterior fin has reached a near-functional size but prior to resorption of the posterior fin. The dashed line represents a Reynolds number isopleth at $R_{\mathrm{C}}=1000$. An $R_{\mathrm{c}}$ in excess of 1000 is preferable for lift-based fin propulsion (Webb and Weihs, 1986). 
activities are much lower than those of $L$. opalescens at any given size. Obviously, similar enzymatic activities do not result in similar locomotory abilities in differently sized animals. A knowledge of the scaling relationships is essential before appropriate comparisons can be made.

In loliginid and ommastrephid cephalopods, the primary means of locomotion is jet propulsion using mantle contractions. Because of the high tissue density in some squids, fin swimming may not be sufficient even to allow stationary hovering (O'Dor and Webber, 1991). Correspondingly, the activities of both CS and ODH in the mantle muscle of these cephalopods are considerably higher than the activities of these respective enzymes from any tissue measured in the present study $\left(8.0 \pm 0.1\right.$ and $132 \pm 5.4$ units $^{-1}$, respectively, for the loliginid $L$. opalescens and $4.9 \pm 1.2$ and $1454 \pm 47$ units $^{-1}$, respectively, for the ommastrephid Stenoteuthis oualaniensis $\left(25^{\circ} \mathrm{C}\right.$ measurement temperature; Ballantyne et al. 1981; Baldwin, 1982). The ODH activities in mantle muscle of $S$. oualaniensis are 140 times those in $V$. infernalis mantle muscle (Baldwin, 1982). Even the retractor muscle ODH activities of Nautilus pompilius are four times the highest fin activity in $V$. infernalis (Baldwin, 1982). It is important to keep in mind that the values compared above were measured at $20^{\circ} \mathrm{C}$ and $25^{\circ} \mathrm{C}$, respectively, for $V$. infernalis and the other cephalopods. At in situ temperatures, assuming a typical $\mathrm{Q}_{10}$ of 2.0, the enzymatic activities of $V$. infernalis could be as much as 500 times lower than those of $S$. oualaniensis (for further discussion, see Childress and Somero, 1979). It is also important to remember that these activities were measured under non-limiting substrate conditions and that, while we believe that they generally reflect in vivo metabolic requirements (a contention supported by the scaling similarity between CS activity and $\dot{M}_{\mathrm{O}_{2}}$ ), they are not direct measurements of in vivo metabolic flux.

Hunt (1996) reports that $V$. infernalis is capable of swimming more rapidly than most midwater (mesobathypelagic) cephalopods with the exception of the more muscular squids such as the gonatids. From in situ observations using a remotely operated vehicle, Hunt (1996) estimated a burst swimming speed for $V$. infernalis (size unknown) of up to 2 body lengths $\mathrm{s}^{-1}$. The energy required to overcome drag is proportional to the cube of velocity. Small errors in velocity estimates therefore result in large errors in cost calculations. However, as controlled swimming experiments have never been performed on deep-water cephalopods, in situ observations will have to suffice. A speed of 2 body lengths $\mathrm{s}^{-1}$ is roughly twice the specific burst speed of Nautilus pompilius but less than $40 \%$ of that of the ommastrephid Illex illecebrosus of similar size (O'Dor et al. 1990). This translates into a more than 15-fold difference in cost between $V$. infernalis and I. illecebrosus not accounting for the differences in swimming behavior and body shape. Even more important is the duration of swimming. Nautilus pompilius does not reach the same length-specific speeds as $V$. infernalis but it can sustain its maximum speed for several minutes, a possible advantage when encountering currents along reefs (O'Dor $e t$ al. 1990). Epipelagic squids are more likely to have lengthy interactions with predators and prey in their well-lit environment, where predator/prey detection distances are great. To be hidden in its darkened habitat, however, $V$. infernalis only needs to get out of immediate reach of a predator without revealing the general direction of its new location. The low buffering capacities reported for $V$. infernalis mantle muscle (Seibel et al. 1997) suggest extremely shortduration burst swimming (although buffering capacity has not been measured in fin tissue). The statocysts of $V$. infernalis are intermediate between those of the teuthoids and the octopods, with some characteristics that suggest reasonable agility (Stephens and Young, 1976). Recently described bioluminescent displays combined with many rapid turns may allow $V$. infernalis to be safely hidden only a few meters from a pursuing predator (Herring et al. 1994; Hunt, 1996).

In general morphology, Vampyroteuthis infernalis is most comparable to the cirrate, or finned, octopods. Cirrate octopods are generally deep-living and are associated with the benthos. They are similar to $V$. infernalis in having large diamondshaped fins, an extensive webbing between the arms and a gelatinous musculature (Aldred et al. 1983; Hochberg et al. 1992). Contrary to earlier reports (Roper and Brundage, 1972), the mantle does not appear to function in the locomotion of cirrate octopods (Vecchione and Young, 1997; Villanueva et al. 1997). Unidentified Opisthoteuthis species have been seen from submersibles swimming primarily with the arms in a manner similar to a jellyfish (Vecchione and Roper, 1991). This is consistent with the enzyme activities measured here. Opisthoteuthis californiana has lower CS and ODH activities in the fin than those of a similar-sized vampire squid (Table 1). Enzymatic activity in arm tissue, however, is considerably higher than that found in $V$. infernalis (Table 1). Like fin swimming, medusoid swimming is much more efficient than jet propulsion owing to the large masses and low velocities of the water expelled. The relatively high enzymatic activity in arm muscle of $O$. californiana could also be required for faststart escape reactions or for crawling along the bottom (Villanueva et al. 1997). The locomotory behavior of the cirroteuthid Cirrothauma murrayi has also been described from a submersible (Aldred et al. 1983; Villanueva et al. 1997). Fin swimming appears to be the main mode of locomotion in C. murrayi (Villanueva et al. 1997), and mantle contractions were observed only during respiration (although respiration and locomotion are tightly coupled in cephalopods). C. murrayi has a higher CS activity in mantle than in fin tissue and appears to have a much lower enzymatic activity in fin muscle than would a hypothetical $V$. infernalis of similar mass (approximately $3000 \mathrm{~g}$ ). Perhaps mantle is more important for locomotion than previously suggested. ODH activity is higher in fin than in either mantle or arm tissue of $C$. murrayi, indicating that fins are important at least for burst escape responses. Because the present specimen of $C$. murrayi was apparently killed by heat shock or pressure upon capture (see Materials and methods), it is possible that some enzymatic activity was lost prior to freezing of tissue samples. It is not 
known how enzymatic activity scales in any cirrate octopods. It appears that the young cirrates, unlike $V$. infernalis, have proportionally larger fins than the adults (Hochberg et al. 1992). Perhaps fin swimming is important at all sizes for cirrate octopods.

\section{Scaling}

The CS activity of Vampyroteuthis infernalis was higher in fin $_{\mathrm{a}}$ muscle (Fig. 4) than in mantle (Fig. 2) or arm (Fig. 3) muscle at all adult sizes. ODH activities in anterior fin (fin ${ }_{a}$; Fig. 5) tissue were significantly higher than in arm tissue (Fig. 3) and higher, on average, than in mantle tissue (Fig. 5), although the intercepts of the scaling curves are not significantly different $(P=0.06)$. This supports the suggestion that fin swimming is of greater relative importance than jet propulsion using mantle contractions in $V$. infernalis and is in agreement with similar trends suggested for other deep-living pelagic cephalopods (Seibel et al. 1997). CS activity in fin tissue of adult $V$. infernalis increased significantly with wet body mass (Fig. 4), while CS activity in mantle (Fig. 2) and arm (Fig. 3) tissue decreased with a slope similar to that of the rate of oxygen consumption (Seibel et al. 1997). The proximal cause of these scaling relationships may be changes in the relative abundance of oxidative and glycolytic muscle fibers through ontogeny, as was observed in Loligo opalescens mantle muscle (Preuss et al. 1997). The ultimate or evolutionary causes of the observed scaling patterns are not easily determined. The scaling of CS activity in $V$. infernalis suggests that fin propulsion becomes either increasingly more important or more costly in larger animals relative to jet propulsion. The latter possibility depends on there being some selection for the maintenance of similar sustained lengthspecific swimming speeds at all sizes. O'Dor and Webber (1991) argue that foraging volume increases only as the square of body length while mass increases as its cube, unless cruising speeds are length-specific.

Adult Vampyroteuthis infernalis appear to be geometrically similar throughout the size range (Pickford, 1949). Geometric similarity does not, however, necessarily imply equivalent levels of activity in large and small animals at a given lengthspecific swimming speed (Drucker, 1996). Larger fins (in larger animals) imply smaller fin angular velocities and fin-beat frequencies. To swim at the same absolute velocity, a smaller animal must flap its fins more often than a larger one (Bannasch, 1994). However, to swim at the same relative velocity (body lengths $\mathrm{s}^{-1}$ ), a larger animal has to produce considerably more thrust than a smaller animal.

Drucker (1996) reported a gait-transition compression in the surf perch Embiotoca lateralis Agassiz. The switch from pectoral fin propulsion to caudal fin undulation occurs at lower length-specific speeds in larger animals. In larger animals, pectoral fin propulsion may be less effective at generating length-specific speeds than caudal fin undulation. Assuming selection for the maintenance of similar sustainable lengthspecific speeds at all sizes, the concentration of enzymes in propulsive muscles ( $\mathrm{fin}_{\mathfrak{a}}$ ) of Vampyroteuthis infernalis may increase to counteract the higher costs of fin swimming at larger sizes.

Mass-specific aerobic metabolic rate typically decreases with increasing body mass. The hypotheses that have been put forward to explain this phenomenon generally fall into two categories; geometric constraints and geometric opportunities, both a result of the slower rate of increase of surface area and cross section of a solid as its mass increases (Childress and Somero, 1990). Constraint hypotheses suggest that scaling rules for solids impose constraints on the design of animals such that some surface- or cross-section-limited supply or removal processes (e.g. gas exchange or digestion) increase more slowly than does mass. Childress and Somero (1990) argued convincingly against a constraints hypothesis based on the conserved slope $(b=-0.25)$ among metabolic scaling relationships across taxa despite vast differences in the elevations of the various curves. They argue that the usual negative allometry of aerobic metabolism is due instead to increased (geometric) opportunities for energy savings in larger animals as a result of reduced costs for such processes as thermoregulation in mammals or ion regulation in fishes (Childress and Somero, 1990).

Childress and Somero (1990) also discussed the scaling of glycolytic enzyme activity in fishes and concluded that the positive scaling coefficients for locomotory muscles represented an adaptation for size-independent acceleration used during predator-prey interactions. Larger animals are required to accelerate proportionally faster than smaller animals to escape predators or capture prey. The positive scaling of $V$. infernalis mantle, anterior fin (Fig. 5) and arm (Fig. 3) tissue ODH activity therefore suggests that all three tissues are important for burst escape locomotion. This is supported by shipboard (Young, 1964) and in situ (Hunt, 1996) observations.

Extrapolating to smaller sizes, Vampyroteuthis infernalis mantle muscle has higher CS (and possibly ODH) activities than does fin $_{\mathrm{a}}$ tissue (Figs 4, 5). This suggests a trend towards increased use of jet propulsion relative to fin swimming in smaller individuals. This trend has been suggested for other squid species as well (O'Dor and Webber, 1986) and is consistent with the changes in fin complement observed during the transition from juvenile to adult $V$. infernalis. This dramatic change in fin assemblage suggests that 'metamorphosis' may be related largely to the scaling of swimming hydrodynamics. While controlled observations of swimming in bathypelagic cephalopods are completely lacking, and experimental data on the kinematics of fin swimming in general are limited, enough work has been carried out across a broad taxonomic range to warrant some speculation as to the selective pressures driving metamorphosis in $V$. infernalis.

\section{Ontogenetic gait transition}

There are two predominant modes of locomotion using paired fins for propulsion (Vogel, 1994). In drag-based propulsion, the fins are moved back and forth along the axis of progression, oriented broadside to the flow during the 
backward power stroke and parallel to the flow during the forward recovery stroke. The backward stroke develops much more drag, equivalent to forward thrust. Drag-based propulsion is efficient only at low speeds when the velocity of the fins is large compared with the overall motion of the body. In liftbased propulsion, the fins are moved up and down in a plane perpendicular to the axis of progression (Fig. 7). By rotating the fins along their length, an appropriate angle of attack can be maintained to generate enough lift from circulation so that there is a net forward thrust (Fig. 8; Vogel, 1994). Lift-based propulsion is efficient at higher speeds where water flow over the fins is sufficient to create the required thrust.

The Reynolds $\left(R_{\mathrm{c}}\right)$ number, the ratio of inertial to frictional forces, for lift-based fin propulsion is based on the chord length
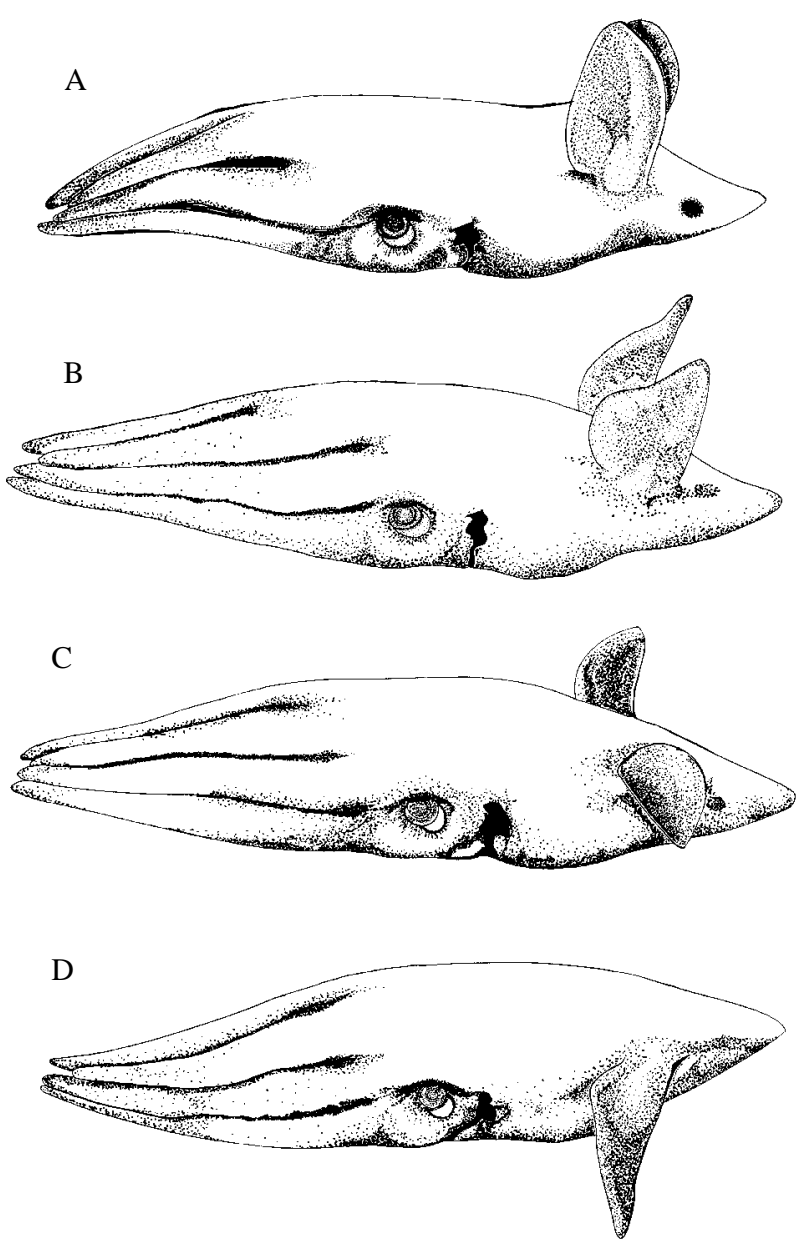

Fig. 7. An adult (mantle length $62 \mathrm{~mm}$ ) Vampyroteuthis infernalis showing hypothetical lift-based propulsive series (based on shipboard observations and photographs from the present study and on still frame analysis from deGruy and Brown, 1995). (A) Anterior fins at the top of the propulsive stroke. The arms are bent or flexed downward as a result of, or to compensate for, lift-derived pitch. (B) Fins beginning the downstroke. (C) The angle of incidence of approximately $45^{\circ}$ (defined in Fig. 8) of the anterior fins on the downstroke can be seen. (D) Anterior fins at the bottom of the propulsive stroke. The arms are flexed or bent upwards as a result of, or to compensate for, pitch on the downstroke. of the fins, the absolute velocity and the kinematic viscosity of sea water. Webb and Weihs (1986) state that the $R_{\mathrm{c}}$ must be in the hundreds, and preferably greater than 1000 , before liftbased mechanisms can be effective. Fig. 6 presents the $R_{\mathrm{c}}$ values calculated assuming lift-based propulsion for the posterior and anterior fins of $V$. infernalis. $R_{\mathrm{c}}$ values for the posterior fins range from 28 to 66 . These values are low compared with the range of $R_{\mathrm{c}}$ for the anterior fins (160-14000), suggesting that juvenile $V$. infernalis are incapable of lift-based propulsion. Not until metamorphosis is complete do the anterior fin $R_{\mathrm{c}}$ values exceed 1000 , the minimum value for lift-based propulsion.

Juvenile Vampyroteuthis infernalis appear to have functional fins, but their fins are more slender than those of the adults. Pickford (1949) reports that the mean fin $\mathrm{p}$ index (chord length $\times 100 / \mathrm{ML}$ ) is 26 compared with 49 for adult fin . Small, narrow fins combined with lower absolute swimming speeds at smaller sizes must preclude all but drag-based fin propulsion in juveniles because water flow over the fins is insufficient for lift-based propulsion (Lauder and Jayne, 1996; Westneat, 1996; Vogel, 1994; Webb and Weihs, 1986). The far-posterior insertion and transverse orientation of the blade of the posterior fins also limit $V$. infernalis juveniles to drag-based propulsion. The adult fin is inserted more anteriorly than the posterior fin (Fig. 1C,D). It is diamond-shaped and is oriented so that the natural motion of the fins is perpendicular to the direction of swimming, all consistent with lift-based propulsion (Lauder and Jayne, 1996).

The low enzymatic activities in both fin $_{\mathrm{p}}$ and $\mathrm{fin}_{\mathrm{a}}$ tissue and the relatively high activity in mantle muscle prior to metamorphosis indicate that jet propulsion using mantle muscle is the primary means of propulsion in juvenile $V$. infernalis. The increase in CS activity with size after metamorphosis suggests an increased use of the fins for liftbased propulsion. The change in the relative proportions of mantle and arm lengths is also consistent with a reduction in the capacity for jet propulsion in larger individuals. Fin propulsion in loliginids and ommastrephids consists primarily of undulatory wave propulsion. As in drag-based swimming, the undulatory wave must move backwards faster than the animal's forward progression to be effective. Therefore, fins contribute thrust only at low speeds in epipelagic squids (O'Dor, 1988). Lift-based mechanisms are not constrained in this way (Vogel, 1994) and so, in V. infernalis, contribution to thrust may theoretically continue to speeds much higher than those achieved with fins by other cephalopods.

A side-effect of lift-based propulsion is pitching of the body against the fin stroke. As the fins rise on the upstroke or fall on the downstroke, the posterior part of the squid falls or rises, respectively, as a necessary result of lift production. Pitching has been observed to occur in birds (Thomas, 1997), including penguins (Clark and Bemis, 1979), marine turtles (Davenport et al. 1984), pteropod molluscs (Satterlie et al. 1985) and, from our own observations, Vampyroteuthis infernalis. Compensation for pitch is accomplished using the head in sea turtles and the tail in flying birds and pteropods. Fig. 7A clearly shows the arms of 


\begin{abstract}
Fig. 8. Diagram depicting the origin of thrust from lift-based aquatic 'flight'. The fin element (cross section) is approximated from Fig. 7C. The oncoming flow of water seen by this fin element, $U_{\mathrm{w}}$, is the resultant of two component water flows. $U_{\mathrm{f}}$ is the flow due to the animal's forward motion and $U_{\mathrm{d}}$ is the flow due to the downward motion of the fins. The fin element is set at an angle relative to the line of progression (the angle of incidence) that results in a small angle of attack (the angle relative to $U_{\mathrm{w}}$ ). Such an angle of attack gives good lift and low drag. The resultant of the lift and drag components is tipped forward of the vertical and therefore has both a lift and a thrust component (top right) (derived from Vogel, 1994).
\end{abstract}

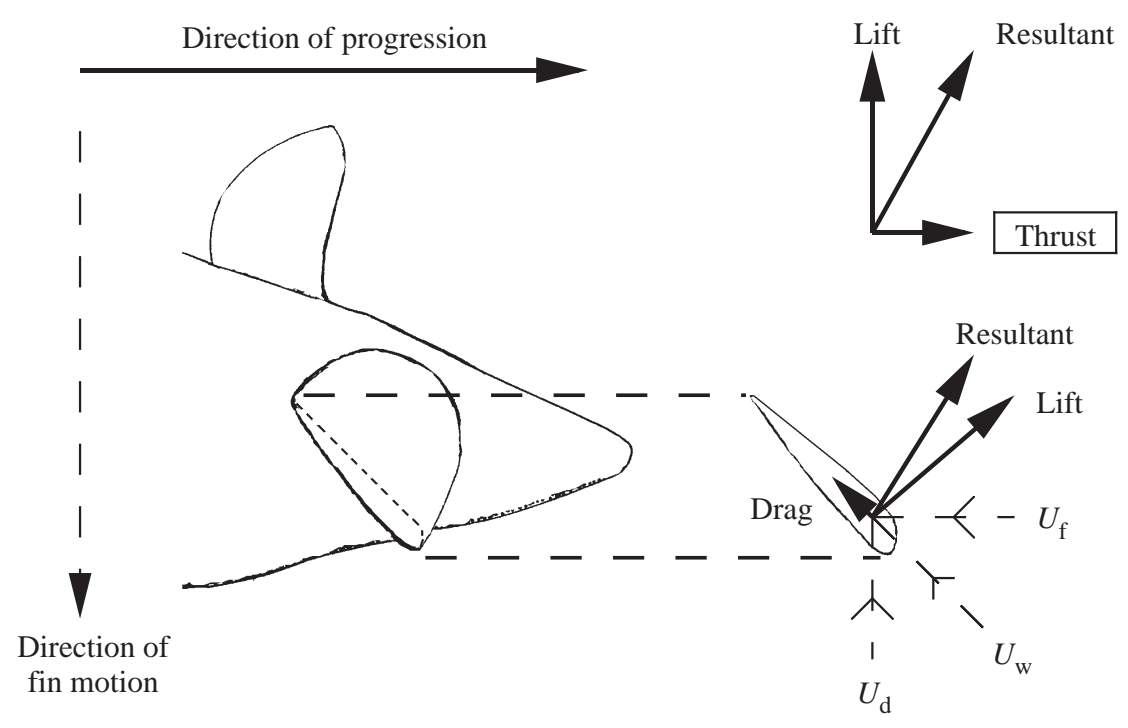

$V$. infernalis bent downwards during the upstroke of the fins, and Fig. 7D shows similar compensation during the downstroke. The increased length of the arms relative to mantle length in adult $V$. infernalis (Pickford, 1949) may aid in counter-balancing the pitch produced during lift-based propulsion.

Adult $V$. infernalis appear to use a drag-based propulsion mechanism only when accelerating. Hunt (1996) described broad sweeping fin $_{\mathrm{a}}$ beats during escape acceleration, with the fins being pulled flush along the mantle and the direction of fin motion being opposite to progression. Fin beats were accompanied by pulses from the mantle. During sustained swimming, however, he described a figure-of-eight motion of the anterior fins (see also deGruy and Brown, 1995). Figureof-eight movements are consistent with a changing angle of attack during lift-based aquatic 'flight' (Lauder and Jayne, 1996) or opposing motions for stability when holding position in the water column. Of course, nothing prevents an animal from using a combination of drag- and lift-based propulsion, even using the same appendage.

Hoar et al. (1994) suggested that the small, paddle-shaped fins of juvenile squids may be important for stabilization rather than for propulsion. This may be the case for juvenile $V$. infernalis as well. Assuming a fin $\mathrm{p}_{\mathrm{p}}$ length of approximately $5 \%$ of body length and taking the length of a propulsive stroke of the fin to its maximum of twice fin length, the posterior fins would have to beat at at least $10 \mathrm{~Hz}$ to reach 2 body lengths s ${ }^{-1}$ using drag-based propulsion, even at $100 \%$ efficiency. Of course, efficiency will be much lower. Assuming a total blade area of the posterior fins of approximately $1 \%$ of the crosssectional area of the animal, efficiency may be closer to $1 \%$. A speed of 2 body lengths $\mathrm{s}^{-1}$ would then require the posterior fins to beat at $1000 \mathrm{~Hz}$ ! Therefore, at all but the lowest speeds, the contribution of the posterior fins to thrust is minimal. Stability is a more likely role for the posterior juvenile fins.

Enzymatic activity scaling relationships and changes in fin complement through ontogeny of Vampyroteuthis infernalis suggest that there is a transition from jet propulsion in juveniles to lift-based fin propulsion as the primary means of locomotion in adults. This is consistent with the observations of O'Dor and Webber (1986) that cost of transport scales differently for jet propulsion and fin swimming such that, at small sizes, jet propulsion may actually be more efficient than fin propulsion. The transition from posterior to anterior fins in $V$. infernalis appears to function as an ontogenetic gait-transition, analogous to the first development of paired fins in many fishes (Webb, 1994).

We thank R. E. Young, D. L. Cowles and F. G. Hochberg for constructive comments on the manuscript. We are grateful to the captains and crews aboard the research vessels New Horizon, Robert Gordon Sproul and Point Sur for their assistance at sea. We thank the Monterey Bay Aquarium and the Monterey Bay Aquarium Research Institute for allowing participation on several research cruises. We thank Marcus Biondi for providing illustrations, J. Hunt, C. Braby and R. Villanueva for informative discussions concerning deep-sea cephalopods and A. Zimmerman, T. van Meeuwen and John Freytag for their assistance at sea. We also thank anonymous reviewers for helpful suggestions and criticisms. This research was supported by NSF grants OCE-9301374, OCE-9415543 and OCE-9115551 to J. J. C.

\section{References}

Aldred, R. G., Nixon, M. AND Young, J. Z. (1983). Cirrothauma murrayi Chun, a finned octopod. Phil. Trans. R. Soc. Lond. B 301, $1-54$.

BALDWIN, J. (1982). Correlations between enzyme profiles in cephalopod muscle and swimming behavior. Pac. Sci. 36, 349-356.

BALDWIN, J. AND ENGLAND, W. R. (1980). A comparison of anaerobic energy metabolism in mantle and tentacle muscle of the blue-ringed octopus, Hapalochlaena maculosa, during swimming. Aust. J. Zool. 28, 407-412.

Ballantyne, J. S., HochachKa, P. W. And Mommsen, T. P. (1981). Studies on the metabolism of the migratory squid, Loligo opalescens: enzymes of tissues and heart mitochondria. Mar. Biol. Lett. 2, 75-85. 
BANNASCH, R. (1994). Functional anatomy of the 'flight' apparatus in penguins. In Mechanics and Physiology of Animal Swimming (ed. L. Maddock, Q. Bone and J. M. V. Rayner), pp. 163-192. Cambridge: Cambridge University Press.

Beebe, W. (1926). The Arcturus Adventure. New York: G. P. Putmans. 354pp.

Berry, S. S. (1949). A new Opisthoteuthis from the eastern Pacific. Leafl. Malac. 1, 23-26.

Bone, Q., Pulsford, A. And Chubb, A. D. (1981). Squid mantle muscle. J. mar. biol. Ass. U.K. 61, 327-342.

ChILdRess, J. J. (1995). Are there physiological and biochemical adaptations of metabolism in deep-sea animals? Trends Ecol. Evol. 10, 30-36.

Childress, J. J., Barnes, A. T., Quetin, L. B. And Robison, B. H. (1978). Thermally protecting cod ends for recovery of living deepsea animals. Deep-Sea Res. 25, 419-422.

Childress, J. J. AND Mickel, T. J. (1980). A motion compensated ship-board precision balance system. Deep-sea Res. 27A, 965-970.

Childress, J. J. ANd Somero, G. N. (1979). Depth-related enzymic activities in muscle, brain and heart of deep-living pelagic marine teleosts. Mar. Biol. 52, 273-283.

ChILdRESS, J. J. AND Somero, G. N. (1990). Metabolic scaling: a new perspective based on scaling of glycolytic enzyme activities. Am. Zool. 30, 161-173.

Chun, C. (1903). Aus den Tiefen des Weltmeeres (ed. G. Fischer). Jena.

Chun, C. (1913). Cephalopoda from the 'Michael Sars' North Atlantic deep-sea expedition 1910. Rep. scient. Results Michael Sars N. Atlant. deep sea Exped. 3, 1-21.

Clark, B. D. AND Bemis, W. (1979). Kinematics of swimming of penguins at the Detroit Zoo. J. Zool., Lond. 188, 411-428.

Clarke, M. R. (1988). Evolution of buoyancy and locomotion in recent cephalopods. In The Mollusca, vol. 12, Paleontology and Neontology of Cephalopods (ed. M. R. Clarke and E. R. Trueman), pp. 203-213. San Diego: Academic Press.

Cole, S. K. AND Gilbert, D. L. (1970). Jet propulsion of squid. Biol. Bull. mar. biol. Lab., Woods Hole 138, 245-246.

Davenport, J., MunKs, S. A. AND OxFord, P. J. (1984). A comparison of the swimming of marine and freshwater turtles. Proc. R. Soc. Lond. B 220, 447-475.

DEGruY, M. AND BRown, R. (1995). Incredible Suckers. New York: Nature Video Library. Oxford Scientific Films.

DrUCKER, E. G. (1996). The use of gait transition speed in comparative studies of fish locomotion. Am. Zool. 36, 555-566.

FeldKAMP, S. D. (1987). Swimming in the California sea lion: morphometrics, drag and energetics. J. exp. Biol. 131, 117-135.

Herring, P. J., Dilly, P. N. AND CoPE, C. (1994). The bioluminescent organs of the deep-sea cephalopod Vampyroteuthis infernalis (Cephalopoda: Vampyromorpha). J. Zool., Lond. 233, 45-55.

Hoar, J. A., Sim, E., Webber, D. M. And O’Dor, R. K. (1994). The role of fins in the competition between squid and fish. In Mechanics and Physiology of Animal Swimming (ed. L. Maddock, Q. Bone and J. M. V. Rayner), pp. 27-33. Cambridge: Cambridge University Press.

Hochberg, F. G., Nixon, M. And Toll, R. B. (1992). Order Octopoda. In 'Larval' and Juvenile Cephalopods: A Manual For Their Identification (ed. M. J. Sweeney, C. F. E. Roper, K. M. Mangold, M. R. Clarke and S. v. Boletzky). Smithson. Contr. Zool. 513, 213-279.

HunT, J. (1996). The behavior and ecology of midwater cephalopods from Monterey Bay: submersible and laboratory observations. PhD dissertation, UCLA.

KIER, W. M. (1989). The fin musculature of cuttlefish and squid (Mollusca, Cephalopoda): morphology and mechanics. J. Zool., Lond. 217, 23-38.

LAuder, B. G. AND Jayne, B. C. (1996). Pectoral fin locomotion in fishes: testing drag-based models using three-dimensional kinematics. Am. Zool. 36, 567-581.

Mommsen, T. P., Ballantyne, J., MacDonald, D., Gosline, J. And HochachKa, P. W. (1981). Analogues of red and white muscle in squid mantle. Proc. natn. Acad. Sci. U.S.A. 78, 3274-3278.

O'DoR, R. K. (1988). The forces acting on swimming squid. J. exp. Biol. 137, 421-442.

O'Dor, R. K. AND WebBer, D. M. (1986). The constraints on cephalopods: why squid aren't fish. Can. J. Zool. 64, 1591-1605.

O'Dor, R. K. AND WeBBER, D. M. (1991). Invertebrate athletes: tradeoffs between transport efficiency and power density in cephalopod evolution. J. exp. Biol. 160, 93-112.

O'Dor, R. K., Wells, J. AND Wells, M. J. (1990). Speed, jet pressure and oxygen consumption relationships in free-swimming Nautilus. J. exp. Biol. 154, 383-396.

PICKFORD, G. E. (1936). A new order of dibranchiate cephalopods. Anat. Rec. 67, 77.

PICKFORD, G. E. (1949). Vampyroteuthis infernalis Chun an archaic dibranchiate cephalopod. II. External anatomy. Dana Report 32, $1-132$.

Preuss, T., Lebaric, Z. N. AND Gilley, W. F. (1997). Post-hatching development of circular mantle muscles in the squid Loligo opalescens. Biol. Bull. mar. biol. Lab., Woods Hole 192, 375-387.

Roper, C. F. E. AND BRUndage, W. L. (1972). Cirrate octopods with associated deep-sea organisms: new biological data based on deep benthic photographs (Cephalopoda). Smithson. Contrib. Zool. 121, $1-46$.

Satterlie, R. A., LaBarbera, M. and Spencer, A. N. (1985). Swimming in the pteropod mollusc Clione limacina. J. exp. Biol. 116, 189-204.

SCHMidT-Nielsen, K. (1984). Scaling: Why is Animal Size so Important? Cambridge: Cambridge University Press.

Seibel, B. A., Thuesen, E. V., Childress, J. J. and Gorodezky, L. A. (1997). Decline in pelagic cephalopod metabolism with habitat depth reflects differences in locomotory efficiency. Biol. Bull. mar. biol. Lab., Woods Hole 192, 262-278.

Somero, G. N. AND ChILdRESS, J. J. (1980). A violation of the metabolism-size scaling paradigm: activities of glycolytic enzymes in muscle increase in larger-size fish. Physiol. Zool. 53, 322-337.

Somero, G. N. AND ChILDRESS, J. J. (1985). Scaling of oxidative and glycolytic enzyme activities in fish muscle. In Circulation, Respiration and Metabolism (ed. R. Gilles), pp. 250-262. Berlin: Springer-Verlag.

Stephens, P. R. AND Young, J. Z. (1976). The statocyst of Vampyroteuthis infernalis (Mollusca: Cephalopoda). J. Zool., Lond. 180, 565-588.

Thomas, A. L. R. (1997). On the tails of birds: what are the aerodynamic functions of birds' tails, with their incredible diversity of form? Bioscience 47, 215-225.

Thuesen, E. V. And Childress, J. J. (1994). Respiratory rates and metabolic enzyme activities of oceanic California medusae in relation to body size and habitat depth. Biol. Bull. mar. biol. Lab., Woods Hole 187, 84-98.

VecChione, M. AND Roper, C. F. E. (1991). Cephalopods observed 


\section{B. A. Seibel, E. V. Thuesen and J. J. Childress}

from submersibles in the Western North Atlantic. Bull. mar. Sci. 49, 433-445.

Vecchione, M. AND Young, R. E. (1997). Aspects of the functional morphology of cirrate octopods: locomotion and feeding. Vie Milieu 97, 101-110.

Villanueva, R., Nozais, C. And Boletzky, S. V. (1995). The planktonic life of octopuses. Nature 377, 107.

Villanueva, R., Segonzac, M. AND Guerra, A. (1997). Locomotion modes of deep-sea cirrate octopods (Cephalopoda) based on observations from video recordings on the Mid-Atlantic Ridge. Mar. Biol. (in press).

Vogel, S. (1994). Life in Moving Fluids: The Physical Biology of Flow. Princeton, NJ: Princeton University Press.

WEBB, P. W. (1994). The biology of fish swimming. In Mechanics and Physiology of Animal Swimming (ed. L. Maddock, Q. Bone and J. M. V. Rayner), pp. 45-62. Cambridge: Cambridge University Press.
WebB, P. W. AND Weihs, D. (1986). Functional locomotor morphology of early life history stages of fishes. Trans. Am. Fish. Soc. 115, 115-127.

West, G. B., Brown, J. H. And Enquist, B. J. (1997). A general model for the origin of allometric scaling laws in biology. Science 276, 122-126.

Westneat, M. W. (1996). Functional morphology of aquatic flight: kinematics, electromyography and mechanical modeling of labriform locomotion. Am. Zool. 36, 582-598.

YounG, R. E. (1964). The anatomy of the vampire squid. MA thesis. USC.

YounG, R. E. (1967). Homology of the filaments in Vampyroteuthis infernalis. Science 156, 1633-1634.

YounG, R. E. AND VeCChIONE, M. (1996). Analysis of morphology to determine primary sister-taxon relationships within coleoid cephalopods. Am. Malac. Bull. 12, 91-112. 